\title{
Mobile Phone Electromagnetic Waves and Its Effect on Human Ejaculated Semen: An in vitro Study
}

\author{
Srinivas Belur Veerachari, SS Vasan
}

\begin{abstract}
Mobile phones usage has seen an exponential growth recently. With this increasing demand, the amount of electromagnetic radiation (EMR) exposed is also increasing. Hence, we studied the effect of these radiations on ejaculated human semen and speculate the contribution of these harmful radiations in male infertility. Samples exposed to EMR showed a significant decrease in sperm motility and viability, increase in reactive oxygen species (ROS) and DNA fragmentation index (DFI) compared to unexposed group. We concluded that mobile phones emit electromagnetic waves which lead to oxidative stress in human semen and also cause changes in DNA fragmentation. We extrapolate these findings to speculate that these radiations may negatively affect spermatozoa and impair male fertility.
\end{abstract}

Keywords: Electromagnetic radiation, ROS, DFI, Sperm motility, Sperm viability, Male infertility.

How to cite this article: Veerachari SB, Vasan SS. Mobile Phone Electromagnetic Waves and Its Effect on Human Ejaculated Semen: An in vitro Study. Int J Infertility Fetal Med 2012;3(1):15-21.

\section{Source of support: Nil}

Conflict of interest: None declared

\section{INTRODUCTION}

The use of mobile telecommunication services in the last decade has witnessed a drastically increased development and the amount of radiofrequency electromagnetic wave (RF-EMW) exposure in our daily lives has also increased as a result of this. As the usage of mobile phones has risen, so also the concerns regarding the harmful effects of radiations emitted from mobile phones on human health. Repacholi et al reported that World Health Organization (WHO) to protect public health has established the International EMF Project in 1996 to assess the scientific evidence of possible health effects of electromagnetic frequencies in the range of $30 \mathrm{~Hz}$ to $300 \mathrm{GHz} .{ }^{1}$ Despite of extensive research in this field more than a decade, the potential harmful effects of cell phone radiation remain controversial. Agarwal A et al in his study has highlighted the role of mobile phone exposure on sperm motility, morphology and viability, suggesting a reduction in male fertilization potential. ${ }^{2}$ Many studies have examined the

Date of Received: 12-09-11

Date of Acceptance: 19-09-11

Date of Publication: January 2012 relationship of cell phone use and its effect on semen parameters and concluded that mobile phone use may cause a decrease in fertility. ${ }^{3-6}$ To investigate the effects of cell phone radiation on semen parameters in human requires an in vivo exposure study which is not feasible, owing to ethical issues. Various in vitro studies using animal models have consistently demonstrated oxidative stress in different tissues (kidney, endometrium, eye, testis, brain, myocardial tissue and so on) in response to cell phone radiation. ${ }^{7-13}$ These studies have also shown potential beneficial effects of antioxidants, such as melatonin, vitamin $\mathrm{C}$ and vitamin E, on oxidative stress status induced by RF-EMW in animals. However, results of animal studies related to the effects of cell phone radiation on reproductive functions are conflicting. ${ }^{14-19}$ An animal model does not give us valuable information and inference cannot be drawn from it for several reasons, including the smaller dimensions of the testes, the nonpendulous scrotum, the free migration of the testes through the inguinal canal between the abdomen and the scrotum and the unavoidable exposure of the animal's entire body to RF-EMW at the time of the experiment. ${ }^{20}$ Hence, an in vitro model would be the best scientific way to assess the effects of mobile phone exposure. The World Health Organization's recent research agenda for studies on RF suggests that in vitro studies play a supporting role in health risk assessments and are critical to the optimal design of animal and epidemiology studies. ${ }^{21}$ In a study conducted by Erogul et al, reports of exposure of human semen samples to cell phone radiation under in vitro conditions resulting in a decrease in sperm motility (neat semen) after 5 minutes has been documented. ${ }^{22}$ Other investigators like Falzone et al found no effect of RF-EMW on mitochondrial membrane potential of spermatozoa and motility at a specific absorbance rate (SAR) of $2 \mathrm{~W} / \mathrm{kg}^{23}$ However, they showed a decrease in straight-line velocity and beat-cross frequency at an SAR of $5.7 \mathrm{~W} / \mathrm{kg}$. In the present study, our objective was to validate the results of several recent epidemiologic studies by establishing a causeand-effect relationship between RF-EMW emitted from a mobile phone in talk mode and changes in semen parameters. We tested our hypothesis by examining the effects of RF-EMW on sperm motility, sperm vitality, ROS levels and DNA integrity of spermatozoa in unprocessed ejaculated human semen. 


\section{MATERIALS AND METHODS}

The study was approved by the Ankur RITS-Institutional Review Board.

\section{Subjects (Data Collection)}

Semen samples were collected from 20 healthy donors who volunteered for the study after giving written consent. All specimens were collected by masturbation after an abstinence period of 48 to 72 hours and allowed to liquefy completely for 15 to 30 minutes at $37^{\circ} \mathrm{C}$. Following liquefaction, each sample was divided into two aliquots: Exposed group (sample exposed to cell phone radiation) and control group (sample not exposed to mobile phone radiation but kept in identical conditions as the exposed sample).

\section{Exposure of Semen Samples to Electromagnetic Waves}

One aliquot of each divided semen sample was exposed to EMW emitted from a commercially available mobile telephone in talk mode (Sony Ericsson w300i; service provider Bharti Airtel Limited; GSM: Global System for Mobile communication services; $900 \mathrm{MHz}$ frequency; maximum power $<1 \mathrm{~W}$; SAR $1.46 \mathrm{~W} / \mathrm{kg}$ ). This phone model had a loop-shape, omnidirectional antenna placed on the top back of its handset. The distance between the phone antenna and each specimen was kept at $2.5 \mathrm{~cm}$. The duration of exposure was 60 minutes (Fig. 1).

\section{Power Density $\left(\mu \mathrm{W} / \mathrm{cm}^{2}\right)$}

According to the International Commission for Non-ionizing Radiation Protection (ICNIRP 1998) ${ }^{24}$ and the Federal Communications Commission (FCC 1999), ${ }^{25}$ the reference level for exposure of RF-EMW is peak power density. It is a commonly used term for characterizing an RF electromagnetic field. Power density was monitored during basal condition (no cell phone radiation) and experimental condition (cell phone in talk mode) in the laboratory throughout the experiment. Power density in the control condition was 0.01 to $0.1 \mu \mathrm{W} / \mathrm{cm}^{2}$. Power density in the experimental condition (during cell phone in talk mode and at $2.5 \mathrm{~cm}$ from cell phone antenna) was 1 to $40 \mu \mathrm{W} / \mathrm{cm}^{2}$.

\section{Frequency and Temperature}

The frequency emitted by the cell phone was confirmed with the help of a RF spectrum analyzer (Kaltman Creations). Both specimens (aliquots) were kept at room temperature to avoid the effect of temperature on ROS formation and semen parameters.

\section{Semen Analysis}

Soon after liquefaction, both the exposed and control samples are analyzed for sperm concentration, motility and viability according to $\mathrm{WHO}$ guidelines 5 th edition. ${ }^{26}$ Analysis was repeated of both the aliquots (control and exposed) after 1 hour of radiation exposure.

\section{ROS Measurement}

Measurement of ROS in the exposed and unexposed aliquots was performed after 1 hour by chemiluminescence assay using luminol (5-amino-2, 3-dihydro-1, 4-phthalazinedione; Sigma Chemical Co, Bengaluru, India). A 100 mmol/1 stock solution of luminol was prepared in dimethyl sulfoxide. For the analysis, $10 \mu \mathrm{l}$ of the working solution $(5 \mathrm{mmol} / \mathrm{l})$ was added to $400 \mu 1$ of neat sperm sample. Chemiluminescence

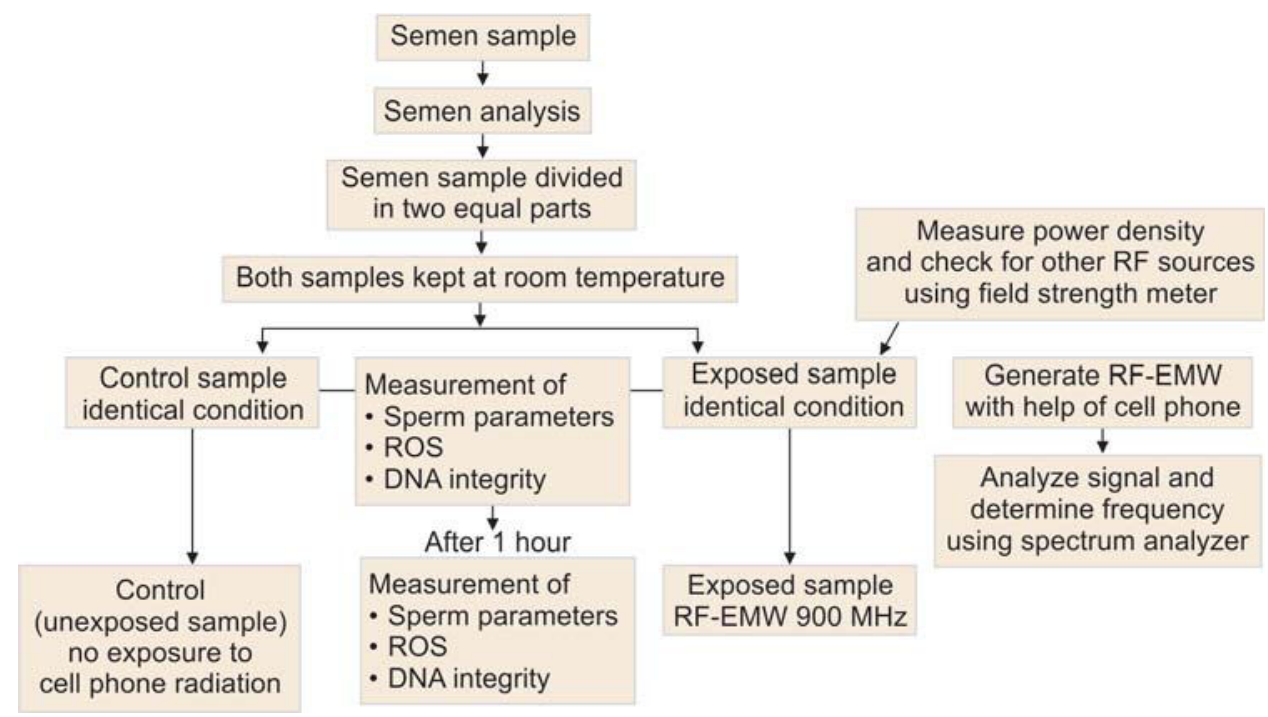

Fig. 1: Study design and set-up for the exposure of semen sample to RF-EMW (RF-EMW: Radiofrequency electromagnetic waves; ROS: Reactive oxygen species) 
was measured for 15 minutes using a Promega luminometer (Promega, Bad-Madison, WI, USA). Results were expressed as $\times 10^{6}$ counted photons per minute $(\mathrm{cpm})$.

\section{DNA Damage}

Sperm DNA fragmentation was evaluated by fluorescence microscopy using acridine orange dye and Halo sperm test. Semen sample $(0.1 \mathrm{ml})$ is added to $0.3 \mathrm{ml}$ of normal saline taken in a clean dry test tube. The sample is centrifuged for 10 minutes at $1000 \mathrm{rpm}$. The supernatant is discarded and $25 \mu \mathrm{l}$ of the pellet is added to $25 \mu \mathrm{l}$ of acridine orange and kept in the dark for 10 minutes. After 10 minutes, $3 \mathrm{ml}$ of normal saline is added to the pellet and centrifuged for 10 minutes at $1000 \mathrm{rpm}$. After centrifugation, supernatant is discarded and pellet is retained. A $5 \mu$ l of the pelleted sample is taken onto a clean dry slide and observed under fluorescence microscope. All red sperms indicate DNA fragmented and green sperms indicate DNA not fragmented. Results of the test were expressed as percentage DNA fragmentation ( $\%$ of DFI).

\section{Statistical Analysis}

Descriptive statistical analysis has been carried out in the present study. Results on continuous measurements are presented on mean \pm SD (min-max) and results on categorical measurements are presented in number $(\%)$. Significance is assessed at 5\% level of significance.

Student t-test (two tailed, dependent) has been used to find the significance of study parameters on continuous scale within each group (sperm count) and Wilcoxon signed rank test has been used to find the significance of parameters expressed in percentage $(\%)$, effect size computed to estimate the level of effect of exposure to mobile on fertility parameters.

\section{Statistical Software}

The statistical software namely SAS 9.2, SPSS 15.0, Stata 10.1, MedCalc 9.0.1, Systat 12.0 and R environment ver. 2.11.1 were used for the analysis of the data and Microsoft Word and Excel have been used to generate graphs, tables, etc.

\section{RESULTS}

There were no significant difference between study samples and control samples in all parameters of the semen analysis, ROS and DFI as depicted in Table 1.

\section{Sperm Parameters}

No significant difference was seen in sperm concentration between preexposure and postexposure of the study samples $(50.65 \pm 16.96 \mathrm{million} / \mathrm{ml}$ vs $50.55 \pm 17.16$ million/ml). Sperm motility was significantly lower in postexposed study samples compared with preexposure study samples. Mean total motility for preexposed study samples and postexposed study samples was $53.05 \pm 9.29 \%$ and $45.75 \pm 7.49 \%$ respectively $(p<0.001)$. Sperm viability was significantly lower in exposed samples than in unexposed samples $(\mathrm{p}<0.001)$. Mean viability for preexposed study samples and postexposed study samples was $51.30 \pm 5.77 \%$ and $47.70 \pm 5.24 \%$ respectively (Table 2).

\section{Reactive Oxygen Species}

The ROS levels were significantly higher in postexposed study samples than in postexposed study samples (Table 1). The increase in ROS value as a result of exposure was from $31.75 \pm 26.03 \times 10^{6} \mathrm{cpm}$ to $38.10 \pm$ $27.51 \times 10^{6} \mathrm{cpm}$, which was statistically significant with a p-value of less than 0.001 .

\section{DNA Integrity}

Significant difference was also noticed in DNA integrity (\% of DFI) between the preexposure study samples and postexposure study samples $(42.35 \pm 16.01 \%$ vs $49.80 \pm$ $18.22 \%$, p-value $<0.001$ ) (Table 2).

\begin{tabular}{|c|c|c|c|c|}
\hline Variables & Intervention & Study sample & Control sample & $p$-value \\
\hline Sperm count (millions/ml) & Preexposure & $50.65 \pm 16.96$ & $51.10 \pm 17.55$ & 0.935 \\
\hline Viability $(\%)$ & Preexposure & $51.30 \pm 5.77$ & $51.30 \pm 5.77$ & 1.000 \\
\hline \multicolumn{5}{|l|}{ Motility (\%) } \\
\hline - Progressive & Preexposure & $33.15 \pm 6.12$ & $32.05 \pm 6.21$ & 0.576 \\
\hline - Nonprogressive & Preexposure & $19.90 \pm 7.12$ & $20.35 \pm 7.73$ & 0.849 \\
\hline - Immotile & Preexposure & $46.95 \pm 9.28$ & $47.60 \pm 9.46$ & 0.828 \\
\hline $\begin{array}{l}\text { - Total motility (progressive and } \\
\text { nonprogressive) }\end{array}$ & Preexposure & $53.05 \pm 9.29$ & $52.4 \pm 9.46$ & 0.880 \\
\hline $\operatorname{ROS}\left(\times 10^{6} \mathrm{cpm}\right)$ & Preexposure & $31.75 \pm 26.03$ & $31.70 \pm 25.76$ & 0.995 \\
\hline DFI (\%) & Preexposure & $42.35 \pm 16.01$ & $42.86 \pm 15.94$ & 0.922 \\
\hline
\end{tabular}




\section{DISCUSSION}

The exposure to radiofrequency electromagnetic wave (RF-EMW) in our daily lives is constantly raising and this has alarmed the analysis of possible harmful effects on the human health. Recently, Friedman et al showed that RF-EMW stimulate plasma membrane NADH oxidase in mammalian cells and cause production of ROS. ${ }^{27}$ This may be attributed to an increase in the activity of spermatozoal NADH oxidase after RF-EMW exposure. Aitken et al demonstrated that human spermatozoa possess a multiple plasma membrane redox system that shares similarities with transmembrane NADH oxidase. Activation of plasma membrane NADH oxidase may cause production of ROS, ${ }^{27}$ this can be detected by luminol-based chemiluminescence because luminal measures both intra- and extracellular ROS. ${ }^{28}$ Chronic exposure to RF-EMW can decrease the activity of catalase, superoxide dismutase (SOD), and glutathione peroxidase, and thus decrease total antioxidant capacity, but experimental studies designed to measure malonaldehyde level and SOD activity show conflicting results. ${ }^{29}$ Development of oxidative stress or disturbance in free radical metabolism by cell phone radiation has been demonstrated in a few animal studies. ${ }^{16,18}$ Reactive oxygen species are produced continuously by spermatozoa and they are neutralized by antioxidants present in the semen. ${ }^{30}$ When ROS production exceeds the capacity of antioxidants, a state of oxidative stress is created and results in various changes in semen parameters and contributing significantly in male infertility. A decrease in sperm motility and viability is linked to concentration of superoxide anion in semen. When superoxide is produced extracellularly, it can oxidize membrane phospholipids and results in a decrease in viability. ${ }^{31}$ Short-term in vitro exposure to RF-EMW should not cause a decline in sperm concentration; however, chronic oxidative stress may lead to a decrease in sperm count. ${ }^{32}$ Due to methodologic variations, interpretations of studies regarding DNA damage are complicated. Aitken et al demonstrated that exposure of mice to RF-EMW, $900 \mathrm{MHz}$, 12 hours/day for 7 days led to damage to the mitochondrial genome and nuclear beta-globin locus of epididymal spermatozoa. ${ }^{15}$ In contrast, Stronati et al demonstrated no significant DNA damage in human lymphocytes exposed to RF-EMW at SAR of 1 and $2 \mathrm{~W} / \mathrm{kg}$ for 24 hours. ${ }^{33}$ Results of other studies are equally conflicting. ${ }^{34-37}$ Recent data suggest that RF-EMW may not have enough energy to cause DNA damage. ${ }^{38-41}$ The lack of any DNA damage may be explained by the scavenging of free radicals by antioxidants in seminal plasma. ${ }^{30,42,43}$ However, it may induce gene expression of proteins, including heat shock proteins. ${ }^{40,44-46}$

\begin{tabular}{|c|c|c|c|}
\hline Variables & Intervention & Study sample & Control sample \\
\hline \multirow[t]{3}{*}{ Sperm count (millions/ml) } & Preexposure & $50.65 \pm 16.96$ & $51.10 \pm 17.55$ \\
\hline & Postexposure & $50.55 \pm 17.16$ & $51.00 \pm 17.39$ \\
\hline & $p$-value & 0.428 & 0.163 \\
\hline \multirow[t]{3}{*}{ Viability (\%) } & Preexposure & $51.30 \pm 5.77$ & $51.30 \pm 5.77$ \\
\hline & Postexposure & $47.70 \pm 5.24$ & $50.78 \pm 5.98$ \\
\hline & p-value & $<0.001^{* *}$ & $0.042^{*}$ \\
\hline \multicolumn{4}{|l|}{ Motility (\%) } \\
\hline \multirow[t]{3}{*}{ - Progressive } & Preexposure & $33.15 \pm 6.12$ & $32.05 \pm 6.21$ \\
\hline & Postexposure & $25.70 \pm 4.86$ & $31.80 \pm 6.10$ \\
\hline & $p$-value & $<0.001^{* *}$ & 0.276 \\
\hline \multirow[t]{3}{*}{ - Nonprogressive } & Preexposure & $19.90 \pm 7.12$ & $20.35 \pm 7.73$ \\
\hline & Postexposure & $20.05 \pm 6.17$ & $20.50 \pm 6.58$ \\
\hline & $\mathrm{p}$-value & 0.404 & 1.000 \\
\hline \multirow{3}{*}{ - Immotile } & Preexposure & $46.95 \pm 9.28$ & $47.60 \pm 9.46$ \\
\hline & Postexposure & $53.80 \pm 7.95$ & $47.85 \pm 8.91$ \\
\hline & p-value & $<0.001^{* *}$ & 0.285 \\
\hline \multirow{3}{*}{$\begin{array}{l}\text { - Total motility (progressive and } \\
\text { nonprogressive) }\end{array}$} & Preexposure & $53.05 \pm 9.29$ & $52.4+9.46$ \\
\hline & Postexposure & $45.75 \pm 7.49$ & $52.3 \pm 8.97$ \\
\hline & p-value & $0.035^{\star}$ & 1.000 \\
\hline \multirow[t]{3}{*}{$\operatorname{ROS}\left(\times 10^{6} \mathrm{cpm}\right)$} & Preexposure & $31.75 \pm 26.03$ & $31.70 \pm 25.76$ \\
\hline & Postexposure & $38.10 \pm 27.51$ & $33.05 \pm 26.73$ \\
\hline & $\mathrm{p}$-value & $<0.001^{* *}$ & $<0.001^{* *}$ \\
\hline \multirow[t]{3}{*}{ DFI (\%) } & Preexposure & $42.35 \pm 16.01$ & $42.86 \pm 15.94$ \\
\hline & Postexposure & $49.80 \pm 18.22$ & $43.55 \pm 16.76$ \\
\hline & $\mathrm{p}$-value & $<0.001^{* *}$ & $0.059^{* * *}$ \\
\hline
\end{tabular}

*Moderately significant ( $p$-value: $0.01<p \leq 0.05$ )

** Strongly significant ( $p$-value: $p \leq 0.01$ )

${ }^{* * *}$ Suggestive significance ( $p$-value: $\left.0.05<p<0.10\right)$ 
In our study, the sperm DNA integrity did change in the EMW-exposed group compared with the unexposed control samples.

In our study, we gathered data related to the effect of mobile phone radiation (in talk mode) and analyzed the decrease in semen parameters. Our results showed a significant decrease in sperm motility and viability, and a significant increase in ROS production and DNA fragmentation index (DFI \%) in the exposed samples. The increase in ROS levels in RF-EMW-exposed semen samples may be due to the stimulation of the spermatozoa's plasma membrane redox system by RF-EMW or the effect of EMW on leukocytes present in the semen samples. In our study we used unprocessed semen samples, which contain both mature and immature spermatozoa to assess the effect of EMW on sperm function, whereas in a recent study conducted by Falzone et al only mature sperm from the Percoll fraction was used for analysis. ${ }^{23}$ It has been suggested that free radical generating capacity may be higher in spermatozoa in the low-density region of the Percoll gradient (immature spermatozoa) compared with the capacity of sperm from the higher-density fraction (mature spermatozoa). ${ }^{28}$ In a study conducted by Agarwal et al, both normal donors and patients who are infertile were studied and their effects on exposure to RF-EMW were analyzed. ${ }^{20}$ Accordingly, the results showed that there were increase in seminal ROS values in both the donors and the patients, and the increase in ROS levels in exposed samples from patients was significantly higher than the increase in ROS levels in donor samples indicating that immature and abnormal spermatozoa may be more susceptible to mobile phone radiation. This may be explained by the fact that these patients are already with poor quality sperm in terms of both poor motility and abnormal morphology and presence of leukocytes and the radiation exposure will attenuate the response and the results. Therefore, excessive exposure to mobile phone-emitted RF-EMW would be more likely to further deteriorate the sperm quality, after long-term and constant exposure, in both mature as well as immature sperm to a larger extent, thereby increasing the likelihood of these patients being infertile. Various researchers have shown that RF-EMW has no effect on free radical release from immunerelevant cells. ${ }^{47-50}$ Many earlier studies have shown that a $50 \mathrm{~Hz}$ magnetic field at $1 \mathrm{mT}$ induces free radical formation in phagocytes or monocytes. ${ }^{51,52}$

In our study, we selected the duration of RF-EMW exposure and experimental temperature according to guidelines of EMW exposure in an in vitro experiment. Talk time on a mobile phone differs from individual to individual, so deciding the duration for the experimental condition was a complicated matter. Recent in vitro studies on human sperm and human endothelial cell lines have used 1 hour of in vitro exposure. ${ }^{53} \mathrm{~A}$ decline in ROS levels in semen with time at $37^{\circ} \mathrm{C}$ has been demonstrated in a study conducted by Kobayashi et al. ${ }^{54}$ In a study by Esfandiari et al, ROS levels were significantly higher in semen samples stored at a lower temperature $\left(25^{\circ} \mathrm{C}\right.$ vs $\left.37^{\circ} \mathrm{C}\right){ }^{55}$ According to the available guidelines, sensitivity of the experiment should be at the highest level to maximize the possibility of detecting any significant effect(s) of RF-EMW. To maximize the likelihood of observing the deleterious effects in this study, we chose an exposure time of 1 hour at room temperature. The distance of $2.5 \mathrm{~cm}$ was selected to mimic the close proximity of the testis to a cell phone in a trouser pocket (on talk mode) while a person is talking on a Bluetooth. Recent studies have shown that RF-EMW has no thermal effects at SAR $<2 \mathrm{~W} / \mathrm{kg} \mathrm{RF},{ }^{19,56,57}$ yet we monitored the samples at room temperature with a control in identical condition to eliminate other environmental influence on the changes in the semen parameters.

\section{CONCLUSION}

We have demonstrated that mobile phone radiation causes oxidative stress in unprocessed semen and leads to decrease in spermatozoa motility and viability. The fact that many men carry their cell phones in a trouser pocket (or clipped to their belts at the waist) while using Bluetooth can make them more prone to the RF-EMW exposure and can cause changes in semen parameters through oxidative stress and may lead to infertility. Based on our in vitro results, we can speculate that carrying a cell phone in a pocket may cause deterioration in sperm quality, however it is to be remembered that the phone and the male reproductive organs are separated by multiple tissue layers, so to extrapolate these effects which are seen under in vitro conditions to real-life conditions requires further studies and research.

\section{ACKNOWLEDGMENTS}

The authors would like to thank the Andrology Laboratory Department, Ankur Health Care Private Limited, Bengaluru, for their technical help with this study and Dr Suresh KP for his statistical assistance.

\section{REFERENCES}

1. Repacholi MH. Low-level exposure to radiofrequency electromagnetic fields: Health effects and research needs. Bioelectromagnetics 1998;19:1-19.

2. Agarwal A, Deepinder F, Sharma RK, Ranga G, Li J. Effect of cell phone usage on semen analysis in men attending infertility clinic: An observational study. Fertil Steril 2008;89:124-28.

3. Wdowiak L, Wiktor H. Evaluation of the effect of using mobile phones on male fertility. Ann Agric Environ Med 2007;14: $169-72$. 
4. Davoudi M, Brossner C, Kuber W. The influence of electromagnetic waves on sperm motility. Urol Urogynecol 2002;19: 18-32.

5. Fejes I, Zavaczki Z, Szollosi J, Koloszar S, Daru J, Kovacs L, et al. Is there a relationship between cell phone use and semen quality? Arch Androl 2005;51:385-93.

6. Baste V, Riise T, Moen BE. Radiofrequency electromagnetic fields; male infertility and sex ratio of offspring. Eur J Epidemiol 2008;23:369-77.

7. Oktem F, Ozguner F, Mollaoglu H, Koyu A, Uz E. Oxidative damage in the kidney induced by $900-\mathrm{MHz}$-emitted mobile phone: Protection by melatonin. Arch Med Res 2005;36:350-55.

8. Ozguner F, Bardak Y, Comlekci S. Protective effects of melatonin and caffeic acid phenethyl ester against retinal oxidative stress in long-term use of mobile phone: A comparative study. Mol Cell Biochem 2006;282:83-88.

9. Ozguner M, Koyu A, Cesur G, Ural M, Ozguner F, Gokcimen A, et al. Biological and morphological effects on the reproductive organ of rats after exposure to electromagnetic field. Saudi Med J 2005;26:405-10.

10. Balci M, Devrim E, Durak I. Effects of mobile phones on oxidant/antioxidant balance in cornea and lens of rats. Curr Eye Res 2007;32:21-25.

11. Meral I, Mert H, Mert N, Deger Y, Yoruk I, Yetkin A, et al. Effects of 900-MHz electromagnetic field emitted from cellular phone on brain oxidative stress and some vitamin levels of guinea pigs. Brain Res 2007;1169:120-24.

12. Ozguner F, Altinbas A, Ozaydin M, Dogan A, Vural H, Kisioglu AN, et al. Mobile phone-induced myocardial oxidative stress: Protection by a novel antioxidant agent caffeic acid phenethyl ester. Toxicol Ind Health 2005;21:223-30.

13. Oral B, Guney M, Ozguner F, Karahan N, Mungan T, Comlekci S, et al. Endometrial apoptosis induced by a 900-MHz mobile phone: Preventive effects of vitamins E and C Adv Ther 2006;23:957-73.

14. Forgacs Z, Somosy Z, Kubinyi G, Bakos J, Hudak A, Surjan A, et al. Effect of whole-body $1800 \mathrm{MHzGSM}$-like microwave exposure on testicular steroidogenesis and histology in mice. Reprod Toxicol 2006;22:111-17.

15. Aitken RJ, Bennetts LE, Sawyer D, Wiklendt AM, King BV. Impact of radio frequency electromagnetic radiation on DNA integrity in the male germline. Int J Androl 2005;28:171-79.

16. Dasdag S, Ketani MA, Akdag Z, Ersay AR, Sari I, Demirtas OC, et al. Whole-body microwave exposure emitted by cellular phones and testicular function of rats. Urol Res 1999;27:219-23.

17. Dasdag S, Zulkuf Akdag M, Aksen F, Yilmaz F, Bashan M, Mutlu Dasdag M, et al. Whole body exposure of rats to microwaves emitted from a cell phone does not affect the testes. Bioelectromagnetics 2003;24:182-88.

18. Ribeiro EP, Rhoden EL, Horn MM, Rhoden C, Lima LP, Toniolo L. Effects of subchronic exposure to radio frequency from a conventional cellular telephone on testicular function in adult rats. J Urol 2007;177:395-99.

19. Yan JG, Agresti M, Bruce T, Yan YH, Granlund A, Matloub HS. Effects of cellular phone emissions on sperm motility in rats. Fertil Steril 2007;88:957-64.

20. Agarwal A, Desai N, Makker K, Varghese A, Mouradi R, Sharma R, et al. Effects of radiofrequency electromagnetic waves (RF-EMW) from cellular phones on human ejaculated semen: An in vitro pilot study. Fertility and Sterility 2009;92(13):18-25.

21. World Health Organization. WHO research agenda for radio frequency fields. Available at: www.who.int/peh-emf/research/ rf research agenda 2006.pdf.
22. Erogul O, Oztas E, Yildirim I, Kir T, Aydur E, Komesli G, et al. Effects of electromagnetic radiation from a cellular phone on human sperm motility: An in vitro study. Arch Med Res 2006;37: $840-43$

23. Falzone N, Huyser C, Fourie F, Toivo T, Leszczynski D, Franken D. In vitro effect of pulsed $900 \mathrm{MHz}$ GSM radiation on mitochondrial membrane potential and motility of human spermatozoa. Bioelectromagnetics 2007.

24. International Commission on Non-Ionizing Radiation Protection. Guidelines for limiting exposure to time-varying electric, magnetic, and electromagnetic fields (up to $300 \mathrm{GHz}$ ). Health Phys 1998;74:494-522.

25. Federal Communications Commission. Questions and answers about biological effects and potential hazards of radiofrequency electromagnetic fields. Available at: http://www.transition. fcc.gov/Bureaus/Engineering_Technology/Documents/ bulletins/oet56/oet56e4.pdf.

26. World Health Organization. WHO laboratory manual for the examination and processing of human semen-Fifth Edition. WHO Press, World Health Organization, Switzerland 2010. Available at: http://whqlibdoc.who.int/publications/2010/ 9789241547789 eng.pdf.

27. Friedman J, Kraus S, Hauptman Y, Schiff Y, Seger R. Mechanism of short-term ERK activation by electromagnetic fields at mobile phone frequencies. Biochem J 2007;405:559-68.

28. Aitken RJ, Ryan AL, Curry BJ, Baker MA. Multiple forms of redox activity in populations of human spermatozoa. Mol Hum Reprod 2003;9:645-61.

29. Irmak MK, Fadillioglu E, Gulec M, Erdogan H, Yagmurca M, Akyol O. Effects of electromagnetic radiation from a cellular telephone on the oxidant and antioxidant levels in rabbits. Cell Biochem Funct 2002;20:279-83.

30. Sharma RK, Pasqualotto FF, Nelson DR, Thomas AJ Jr, Agarwal A. The reactive oxygen species-total antioxidant capacity score is a new measure of oxidative stress to predict male infertility. Hum Reprod 1999;14:2801-07.

31. Henkel R, Kierspel E, Stalf T, Mehnert C, Menkveld R, Tinneberg HR, et al. Effect of reactive oxygen species produced by spermatozoa and leukocytes on sperm functions in nonleukocytospermic patients. Fertil Steril 2005;83:635-42.

32. Agarwal A, Makker K, Sharma R. Clinical relevance of oxidative stress in male factor infertility: An update. Am J Reprod Immunol 2008;59:2-11.

33. Stronati L, Testa A, Moquet J, Edwards A, Cordelli E, Villani P, et al. $935 \mathrm{MHz}$ cellular phone radiation. An in vitro study of genotoxicity in human lymphocytes. Int J Radiat Biol 2006;82: 339-46.

34. Lai H, Singh NP. Single- and double-strand DNA breaks in rat brain cells after acute exposure to radiofrequency electromagnetic radiation. Int J Radiat Biol 1996;69:513-21.

35. Lixia S, Yao K, Kaijun W, Deqiang L, Huajun H, Xiangwei G, et al. Effects of $1.8 \mathrm{GHz}$ radiofrequency field on DNA damage and expression of heat shock protein 70 in human lens epithelial cells.Mutat Res 2006;602:135-42.

36. McNamee JP, Bellier PV, Gajda GB, Lavallee BF, Marro L, Lemay E, et al. No evidence for genotoxic effects from $24 \mathrm{~h}$ exposure of human leukocytes to $1.9 \mathrm{GHz}$ radiofrequency fields. Radiat Res 2003;159:693-97.

37. McNamee JP, Bellier PV, Gajda GB, Miller SM, Lemay EP, Lavallee BF, et al. DNA damage and micronucleus induction in human leukocytes after acute in vitro exposure to a $1.9 \mathrm{GHz}$ continuous-wave radiofrequency field. Radiat Res 2002;158: 523-33. 
38. Sakuma N, Komatsubara Y, Takeda H, Hirose H, Sekijima M, Nojima T, et al. DNAstrand breaks are not induced in human cells exposed to $2.1425 \mathrm{GHz}$ band CWandW-CDMA modulated radiofrequency fields allocated to mobile radio base stations. Bioelectromagnetics 2006;27:51-57.

39. Tice RR, Hook GG, DonnerM, McRee DI, Guy AW. Genotoxicity of radiofrequency signals I. Investigation of DNA damage and micronuclei induction in cultured human blood cells. Bioelectromagnetics 2002;23:113-26.

40. Belyaev IY, Koch CB, Terenius O, Roxstrom-Lindquist K, Malmgren LO, Sommer W, et al. Exposure of rat brain to 915 MHz GSM microwaves induces changes in gene expression but not double stranded DNA breaks or effects on chromatin conformation. Bioelectromagnetics 2006;27:295-306.

41. Paulraj R, Behari J. Single strand DNA breaks in rat brain cells exposed to microwave radiation. Mutat Res 2006;596: 76-80.

42. Henkel R, Kierspel E, Stalf T, Mehnert C, Menkveld R, Tinneberg HR, et al. Effect of reactive oxygen species produced by spermatozoa and leukocytes on sperm functions in nonleukocytospermic patients. Fertil Steril 2005;83:635-42.

43. Moskovtsev SI, Willis J, White J, Mullen JB. Leukocytospermia: Relationship to sperm deoxyribonucleic acid integrity in patients evaluated for male factor infertility. Fertil Steril 2007;88: 737-40.

44. Leszczynski D, Joenvaara S, Reivinen J, Kuokka R. Nonthermal activation of the hsp27/p38MAPK stress pathway by mobile phone radiation in human endothelial cells: Molecular mechanism for cancer- and blood brain barrier-related effects. Differentiation 2002;70:120-29.

45. Blank M, Goodman R. A mechanism for stimulation of biosynthesis by electromagnetic fields: Charge transfer in DNA and base pair separation. J Cell Physiol 2008;214:20-26.

46. Nylund R, Leszczynski D. Proteomics analysis of human endothelial cell line EA.hy926 after exposure to GSM 900 radiation. Proteomics 2004;4:1359-65.

47. Capri M, Scarcella E, Fumelli C, Bianchi E, Salvioli S, Mesirca $\mathrm{P}$, et al. In vitro exposure of human lymphocytes to $900 \mathrm{MHzCW}$ and GSM modulated radiofrequency: Studies of proliferation, apoptosis and mitochondrial membrane potential. Radiat Res 2004;162:211-18.

48. Lantow M, Lupke M, Frahm J, Mattsson MO, Kuster N, Simko M. ROS release and Hsp 70 expression after exposure to $1,800 \mathrm{MHz}$ radiofrequency electromagnetic fields in primary human monocytes and lymphocytes. Radiat Environ Biophys 2006; 45:55-62.
49. Lantow M, Schuderer J, Hartwig C, Simko M. Free radical release and HSP70 expression in two human immune-relevant cell lines after exposure to $1800 \mathrm{MHz}$ radiofrequency radiation. Radiat Res 2006;165:88-94.

50. Simko M, Hartwig C, Lantow M, Lupke M, Mattsson MO, Rahman Q, et al. Hsp70 expression and free radical release after exposure to nonthermal radio-frequency electromagnetic fields and ultrafine particles in human Mono Mac 6 cells. Toxicol Lett 2006;161:73-82.

51. Frahm J, Lantow M, Lupke M,Weiss DG, Simko M. Alteration in cellular functions in mouse macrophages after exposure to $50 \mathrm{~Hz}$ magnetic fields. J Cell Biochem 2006;99:168-77.

52. Simko M, Droste S, Kriehuber R,Weiss DG. Stimulation of phagocytosis and free radical production in murine macrophages by $50 \mathrm{~Hz}$ electromagnetic fields. Eur J Cell Biol 2001;80: 562-66.

53. Nylund R, Leszczynski D. Proteomics analysis of human endothelial cell line EA.hy926 after exposure to GSM 900 radiation. Proteomics 2004;4:1359-65.

54. Kobayashi H, Gil-Guzman E, Mahran AM, Sharma RK, Nelson DR, Thomas AJ Jr, Agarwal A. Quality control of reactive oxygen species measurement by luminol-dependent chemiluminescence assay. J Androl 2001;22:568-74.

55. Esfandiari N, Saleh RA, Blaut AP, Sharma RK, Nelson DR, Thomas AJ Jr, et al. Effects of temperature on sperm motion characteristics and reactive oxygen species. Int J Fertil Womens Med 2002;47:227-33.

56. AndersonV, Rowley J. Measurements of skin surface temperature during mobile phone use. Bioelectromagnetics 2007;28:159-62.

57. Straume A, Oftedal G, Johnsson A. Skin temperature increase caused by a mobile phone: A methodological infrared camera study. Bioelectromagnetics 2005;26:510-19.

\section{ABOUT THE AUTHORS}

\section{Srinivas Belur Veerachari (Corresponding Author)}

Uroandrologist Consultant, Department of Andrology, Ankur Health Care Private Limited, Bengaluru, Karnataka, India e-mail: drsrinivasbv@hotmail.com

\section{SS Vasan}

Uroandrologist Consultant, Department of Andrology, Ankur Health Care Private Limited, Bengaluru, Karnataka, India 